\title{
THE SERRA LESTE SEDIMENT-HOSTED AU-(PD-PT) MINERALIZATION, CARAJÁS PROVINCE
}

\author{
FERNANDO HENRIQUE BUCCO TALLARICO ${ }^{1}$, CLÁUDIO RODRIGUES COIMBRA ${ }^{2}$ \\ AND CARLOS HENRIQUE CRAVO COSTA ${ }^{2}$
}

\begin{abstract}
The Serra Leste Au-(Pt-Pd) mineralization is hosted by a folded low-grade metasedimentary sequence known as Rio Fresco Formation. The orebodies are located at the hinge zone of a recumbent syncline at the contact between carbonaceous metasiltstone and dolomitic marble. Ore mineralogy includes quartz, kaolinite, goethite, Mn-oxides, muscovite, amorphous carbon together with gold, Pd-Pt-(Hg) minerals and minor $\mathrm{Cu}-\mathrm{Co}-\mathrm{Ni}$-sulfides. The orebodies are oxidized, and hypogene mineralization is not known beyond the base of supergene alteration. The widespread occurrence of the actinolite-calcite pair and the local association with diopside, indicate a minimum of $550{ }^{\circ} \mathrm{C}$ for peak metamorphic temperature of the dolomitic marble. This temperature is inconsistent with the low-grade metamorphic assemblage of metasiltstones, thence with regional metamorphism, and is better accommodated in a thermal-aureole hypothesis. Cooling of the aureole triggered the breakdown of actinolite to calcite + quartz, at temperatures of about $400-450^{\circ} \mathrm{C}$. Later hydrothermal activity, between $230^{\circ} \mathrm{C}$ and $360^{\circ} \mathrm{C}$, developed chlorite alteration and sulfide precipitation in both dolomitic marble and diorite intrusion(s) that crosscut the metasedimentary sequence. The carbonaceous metasiltstone possibly acted as a chemical barrier, triggering focused deposition of precious metals through a rapid decrease of the oxidation conditions of the hydrothermal fluid. This process was possibly coupled with carbonate dissolution of dolomitic marble that triggered open-space-filling processes, developed an external jasperoid envelope around the orebodies and caused a pH increase.
\end{abstract}

Keywords: Carajás Province, Serra Leste, Serra Pelada, gold, palladium, platinum

INTRODUCTION The Itacaiunas Supergroup is an Archean volcano-sedimentary sequence, located in the northern portion of the Carajás Province, on the eastern border of the Archean Amazon Craton (Docegeo 1988, Tassinari and Macambira 1999). The economic significance of this basin derives from the occurrence of a wide variety of ore deposits including iron, manganese as well as a large number of $\mathrm{Cu}-(\mathrm{Au})$ mineralizations stratigraphically and tectonically related, that are collectively known as the Carajás Copper-Gold Belt (e.g. Salobo, Pojuca, Igarapé Bahia - Docegeo 1988). The Serra Leste Deposit, previously known as Serra Pelada Deposit (Meireles and Silva 1988), is distinct from the above mineralizations and constitutes a unique occurrence of sediment-hosted $\mathrm{Au}-(\mathrm{Pd}-\mathrm{Pt})$ mineralization within the Carajás Province.

The aim of this paper is to present the diagnostic geological attributes, i.e. the descriptive model (Barton 1993) of the Serra Leste Deposit, based on the results of field work, including mapping and drill logging. Petrographic, geochemical and mineralogical investigations via XRD, SEM and EMPA, were also performed.
Mineralogical data are presented in wt $\%$, since they are derived from the integration of XRD and modal analysis. Finally, a conceptual (or genetic) model is suggested and discussed.

GEOLOGIC AND TECTONIC SETTING The Serra Leste mineralization is located at the eastern portion of the Carajás Province, $30 \mathrm{~km}$ northeast of the town of Curionópolis, Pará State (Fig. 1). The basement assemblage consists of Archean gneissic and migmatitic rocks of the Xingú Complex (ca. $2.8 \mathrm{Ga}$ - Machado et al. 1991) that does not crop out in the immediate vicinity of the Deposit. The supracrustal sequence comprises a set of Archean metavolcanosedimentary rocks, encompassing mafic-ultramafic schists and minor felsic rocks, iron formations and chert, named the Rio Novo Sequence (Hirata 1982).

The Rio Novo Sequence is intruded by the differentiated maficultramafic Luanga Complex (2763 $\pm 6 \mathrm{Ma}$ - Machado et al. 1991), which hosts chromite and PGE mineralizations (Suita and Nilson 1988, Diella et al. 1995). These rocks are unconformably overlain by

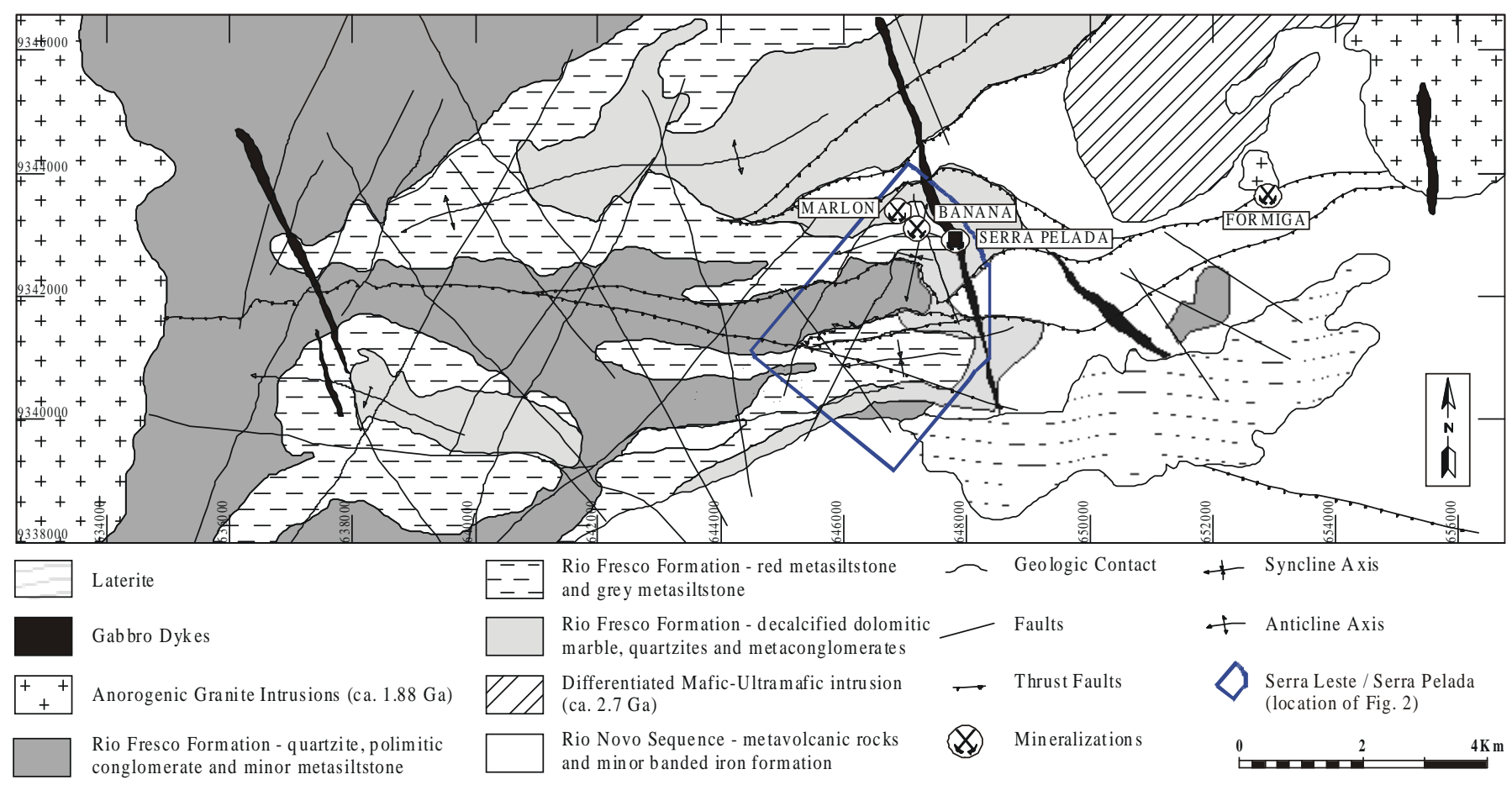

Figure 1-Simplified geological map of the eastern portion of the Carajás Region (modified from Docegeo 1999 unpublished).

1 - Instituto de Geociências, Universidade Estadual de Campinas, Cx. Postal 6152, 13083-970, Campinas, SP. fernando@ige.unicamp.br

2 - Companhia Vale do Rio Doce, Cx. Postal 51, Serra dos Carajás, 68516-000, Parauapebas, PA. clauro@cvrd.com.br, ccravo@cvrd.com.br 
metasedimentary rocks including metaconglomerate, metasandstone, metasiltstone and dolomitic marble of the Rio Fresco Formation (Hirata 1982).

Two distinct episodes of granitoid magmatism occur in the area: one of Proterozoic age, represented by the anorogenic Cigano Granite $(1883 \pm 2 \mathrm{Ma}$ - Machado et al. 1991), and the other represented by small volume of dioritic and granodioritic plugs and dikes of uncertain age.

The Serra Leste Au-(Pd-Pt) mineralization is located at the eastern segment of the Cinzento strike-slip system. This regional E-W trending, steeply dipping fault zone shows evidence of several episodes of movement since $\mathrm{ca}$. 2.7 Ga (Pinheiro and Holdsworth 1997). The Rio Novo Sequence, the Rio Fresco Formation, as well as the Luanga Complex underwent folding and low-grade metamorphism due to reactivation of this strike-slip system (Suita and Nilson 1988 Pinheiro and Holdsworth 1995).

GEOLOGY OF SERRA LESTE The Serra Leste mineralization is hosted by metasedimentary rocks of the Rio Fresco Formation, which include the following units: metaconglomerate, metasandstone, dolomitic marble and metasiltstone (Fig. 2).

The structural evolution of Serra Leste includes two episodes of non-coaxial deformation. The earliest developed tight, recumbent, similar folds with axes plunging $15-25^{\circ}$ southwestwards, to which a weak axial-planar foliation is related. A set of northeast and northwest subvertical fractures and faults overprint the folded structure and control the emplacement orientation of basic dikes.

Clastic Metasedimentary Rocks Metaconglomerate includes iron formation, quartzite and siltstone clasts, ranging from $3 \mathrm{~mm}$ up to $5 \mathrm{~cm}$, set in a fine-grained and foliated quartz-sericite matrix. Metasandstones are poorly sorted and contain quartz grains and quartzite fragments, ranging from fine-grained to a locally conglomeratic nature. Manganese-bearing metasandstone beds occur locally within the sequence. Metasiltstone is characterized by very fine beds of quartz and sericite. The following varieties are mapped: carbonaceous metasiltstone, grey metasiltstone and red metasiltstone. The different colors reflect compositional variations related to the

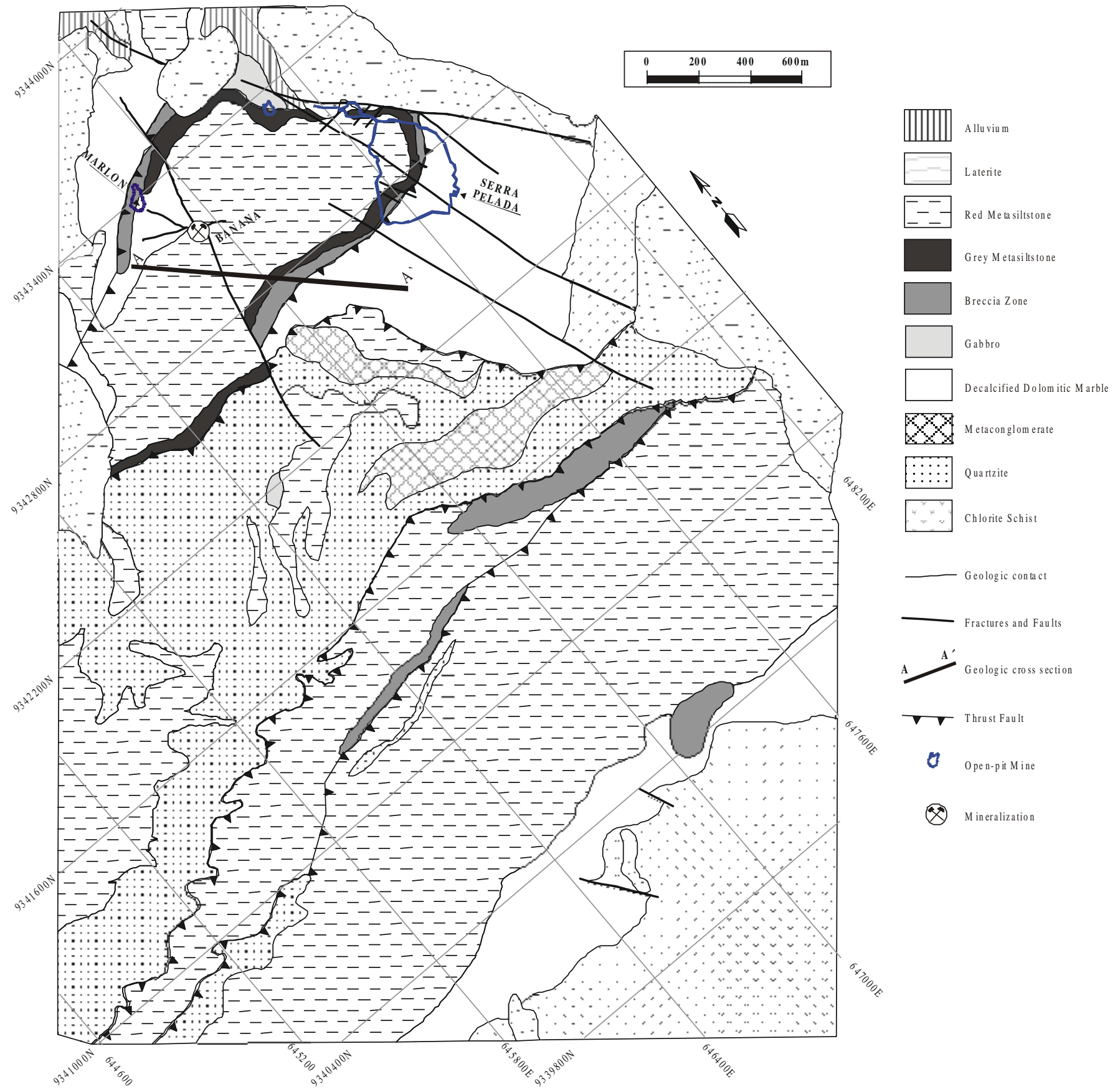

Figure 2-Geological map of the Serra Leste / Serra Pelada Au-(Pd-Pt) mineralization (modified from Docegeo 1995). 
depositional environment. The red color reflects Fe-oxide enrichment, while gray and carbonaceous metasiltones are related to varied proportions of amorphous carbon (2-10 wt\%).

Metamorphic reactions of clastic metasediments are restricted to sericite formation. Tectonic fabric is defined by the orientation of sericite along the axial plane of folds in metaconglomerates and metasiltsones. Metasandstones exhibit weak recrystallization and, locally, the development of a granoblastic fabric.

In the vicinity of the orebodies, the metasiltstones are either brecciated or contain sets of veins with quartz + chlorite \pm calcite \pm tourmaline \pm pyrite \pm chalcopyrite which crosscut the foliation. These vein zones can evolve to breccias where angular metasiltstone fragments are welded by a hydrothermal matrix with same composition of the veins. Euhedral, poikiloblastic spessartine crystals are transgressive to foliation denoting post-tectonic thermal activity.

Dolomitic Marble Dolomitic marble includes rounded quartz grains (1-30 wt \%), and rare iron formation and quartzite fragments in a matrix of granoblastic dolomite (20-85 wt $\%)$ and minor calcite (1-15 $\mathrm{wt} \%)$, with variable amounts of actinolite (5-50 wt\%), chlorite (1-20 $\mathrm{wt} \%)$, biotite $(1-20 \mathrm{wt} \%)$, talc $(1-10 \mathrm{wt} \%)$ and rare diopside. Actinolite-calcite-rich marbles show randomly orientated actinolite crystals that are often altered to a mixture of calcite, talc and chlorite. Talc-chlorite-rich rocks are also enriched in calcite.

Chloritization is the most common and widespread alteration of the dolomitic marble. Actinolite, talc and biotite are altered to chlorite. Chlorite alteration is accompanied by the formation of xenomorphic and poikiloblastic sulfide minerals. Pyrrhotite occurs in equilibrium with pyrite, chalcopyrite and magnetite. Hydrothermal alteration also includes magnetite (up to $20 \mathrm{wt} \%$ ) and muscovite (up to $25 \mathrm{wt} \%$ ) enrichment. Magnetite is partially altered to hematite. Accessory hydrothermal minerals include tourmaline, titanite, allanite, epidote, monazite, apatite, molybdenite, galena and thorite.

Dioritic Intrusion(s) Several drill holes intercepted dioritic rocks at depths between 300-350 m. These rocks occur on the southwest border of the area and are inferred to underlay the mineralization. Country rock is the dolomitic marble, but neither the morphology nor the number of intrusions involved are yet known. These rocks exhibit a hypidiomorphic texture with andesine $(\sim 36 \mathrm{~mol} \% \mathrm{An})$, actinolite and minor ilmenite. The igneous assemblage is hydrothermally altered to albite, sericite, quartz, chlorite, epidote, rutile, and carbonate minerals. Diorites are crosscut by a set of veins containing quartz, epidote, chlorite, sericite and sulfide minerals (pyrite, chalcopyrite and bornite).

Supergene Alteration At Serra Leste, weathering was responsible for the oxidation of clastic metasedimentary rocks and the leaching of dolomitic marble. The base of the oxidation profile, located at a depth of $300 \mathrm{~m}$, is marked by a knife-edge limit between unaltered dolomitic marble and a loose sandy material, with the impregnation of iron and manganese oxide and hydroxide. Volume reduction, caused by decalcification of the dolomitic marble, developed collapse breccia generally enriched in supergenic Mn-oxides. All orebodies at Serra Leste are intensely oxidized, and primary economic mineralization is yet unknown beyond the base of the oxidation profile.

THE Au-(Pd-Pt) Mineralization The Serra Leste Au-(PdPt) mineralization is located in the hinge zone of a recumbent syncline (Fig. 3). Dolomitic marble occurs at the base and is conformably overlain by metasiltones. The morphology of the orebodies broadly follows the contact between dolomitic marble and the carbonaceous metasiltstone that seem to have controlled fluid discharge. The orebodies are surrounded by a silicification zone believed to be originated by the replacement of the dolomitic marble. The result is a 5- to 50-m-thick jasperoid composed of fine-grained quartz in association with traces of sericite, tourmaline, kaolinite, chlorite, hematite, chalcopyrite, and carbonate minerals.

The Au-(Pd-Pt) mineralization is hosted by fine-grained carbonaceous rocks mainly exhibiting isotropic fabric. Brecciated varieties with carbonaceous metasiltstone and minor silicified fragments are also common. The mineralogy is dominated by amorphous carbon (1-10 wt \%), quartz (10-60 wt\%), sericite (1-30 $\mathrm{wt} \%)$, kaolinite (1-20 wt \%), hematite (1-40 wt \%), goethite (1-15 wt $\%)$ and Mn-oxides (1-15 wt\%), with traces of tourmaline, carbonate minerals, chlorite and magnetite.

Owing to the intense supergene oxidation, primary sulfide minerals are rare and are only recognized by SEM investigation. The dominant sulfide minerals are pyrite, chalcopyrite, arsenopyrite, covellite, bornite and galena. Ni-sulfides (millerite and pentlandite) and $\mathrm{Ni}-\mathrm{Co}-(\mathrm{Cu})-$ sulfides (carrolite and siegenite) are responsible for an anomalous geochemical signature of the ore (Co up to $2000 \mathrm{ppm}$, Ni up to 1000 ppm and $\mathrm{Cu}$ up to $4000 \mathrm{ppm}$ ).

Palladium mineralization is related either to $\mathrm{Au}-\mathrm{Ag}-\mathrm{Pd}$ alloys $(\mathrm{Au}$ $\sim 94 \mathrm{wt} \% ; \mathrm{Ag} \sim 3 \mathrm{wt} \%$; Pd $3 \mathrm{wt} \%$ ) or to Pd-Hg-minerals (atheneite and potarite). Platinum minerals are rare and isoferroplatinum is the only identified phase. Gold mineralization is associated with alloys and native gold particles ranging from 4-60 mm in diameter. Supergene alteration played a decisive role in the gold mineralization. Oxidation increased gold fineness and grade, developing giant gold nuggets (up to $62 \mathrm{~kg}$ ) most of which was recovered during the garimpo activity. Gold particles are $45 \%$ associated to gangue (mainly quartz and kaolinite), $44 \%$ to goethite and hematite, $8 \%$ to manganese oxides and $3 \%$ to carbonaceous material.

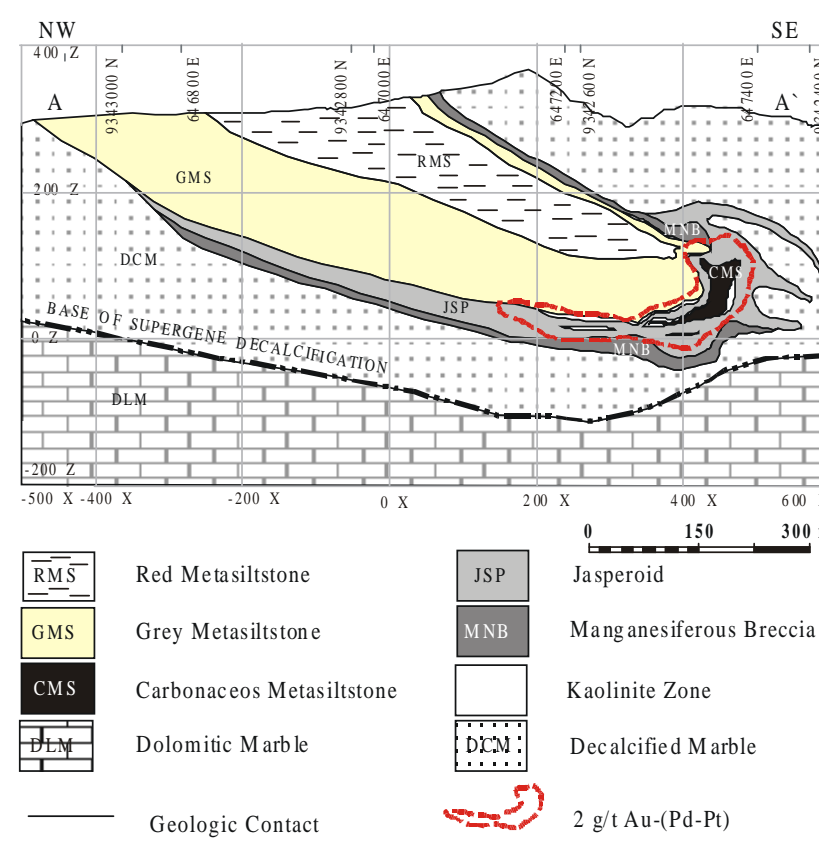

Figure 3-Geological cross section A-A'trough the Serra Leste / Serra Pelada $A u-(P d-P t)$ mineralization (see Fig. 2 for location).

\section{CONTACT METAMORPHISM AND HYDROTHERMAL} ALTERATION Prograde metamorphism of the dolomitic marble is determined by the reaction dolomite + quartz $+\mathrm{H}_{2} \mathrm{O}=$ actinolite + calcite $+\mathrm{CO}_{2}$. The equilibrium tremolite-calcite is stable below $\sim 550^{\circ} \mathrm{C}$ for $\mathrm{XCO}_{2}>0.05$, above which minerals react to form diopside (Tracy and Frost 1991). The widespread occurrence of the pair actinolite-calcite and the local association of diopside, indicate a minimum of $550^{\circ} \mathrm{C}$ for the peak metamorphic temperature. At equivalent temperatures, biotite, aluminium silicates and staurolite or cordierite would be expected in metasiltstones. However, the metasiltstones exhibit a very-low grade metamorphic assemblage and the rare garnet neoblasts are clearly post-tectonic and related to late hydrothermal activity. This thermal gradient is not consistent with the regional metamorphism, being better accounted for by a thermalaureole hypothesis. Additional evidences for contact metamorphism include the presence of hydrothermally altered dioritic intrusion(s) and the mineralogical similarity of the dolomitic marble with other amphibole-rich magnetite skarns (Einaudi et al. 1981, Vidal et al. 1990).

Cooling of the aureole triggered the breakdown of actinolite in accordance with the reaction: tremolite (actinolite) $+\mathrm{CO}_{2}+\mathrm{H}_{2} \mathrm{O}=$ talc + calcite + quartz, at a temperature range of about $400-450^{\circ} \mathrm{C}$ (Tracy and Frost 1991). Later hydrothermal activity developed chlorite 
alteration in association to sulfide precipitation in both dolomitic marble and diorite intrusion(s). Chlorite thermometry (Cathelineau 1988) indicates a thermal range between $230^{\circ} \mathrm{C}$ and $360^{\circ} \mathrm{C}$. The pyrrhotite-pyrite-magnetite association, in the presence of chalcopyrite, denotes high $f \mathrm{O}_{2}\left(\sim 10^{-30}\right.$ to $\left.10^{-31}\right)$ and moderate to high $\mathrm{a}_{\mathrm{SS}}\left(\sim 10^{-1}\right.$ to $10^{-2}$ ) at $300^{\circ} \mathrm{C}$ (Mikucki and Ridley 1993). Late-stage evolution of the hydrothermal system developed hematite and minor bornite, indicating higher oxygen fugacity $\left(>10^{-27}\right)$ and lower sulfur activity $\left(<10^{-3}\right)$. These parameters are consistent with $\mathrm{Au}$ and $\mathrm{Cu}$ mobilization via $\mathrm{Cl}$ complexes (Davidson and Large 1994). Cl-complexes are also efficient in transporting PGE, $\mathrm{Hg}$ and $\mathrm{Ag}$ in oxidized and acid hydrothermal solutions (Mountain and Wood 1988, Watkinson and Melling 1992).

SUGGESTED GENETIC MODEL AND DISCUSSION The

Serra Leste Au-(Pd-Pt) mineralization is tentatively related to the hydrothermal alteration associated with the cooling of the diorite intrusion(s). The solubility of Au and PGE as Cl-complexes are of the same order of magnitude and drop rapidly with $\mathrm{pH}$ increase or $f \mathrm{O}_{2}$ decrease (Mountain and Wood 1988). The carbonaceous metasiltstone possibly acted as a chemical barrier, triggering focused deposition of precious metals through a rapid decrease of oxidation conditions of the hydrothermal fluid. This process was possibly coupled with carbonate dissolution of dolomitic marble that triggered open-space-filling processes, developed an external jasperoid envelope around the orebodies and caused a $\mathrm{pH}$ increase. This depositional model is analogous to other sediment-hosted gold mineralizations (e.g. Berger and Bagby 1993) according to CVRD (1998) and Sillitoe (1998), although the metal content and mineralogical associations are quite distinct.
The source(s) of precious metals are as yet unknown. One can speculate that $\mathrm{Au}, \mathrm{Pd}$ and Pt could have been scavenged from maficultramafic rocks of the Rio Novo Sequence and/or from Luanga-type layered mafic-ultramafic intrusions. The dioritic intrusion(s) and the carbonaceous metasiltstone constitute additional potential for $\mathrm{Au}$ and PGE sources, respectively.

Except for the constraints derived from mineral equilibria, there is no direct data on the fluid. Thus, its source(s) and exact composition(s) are still to be established. However, the association with thorite and REE minerals, coupled with indirect evidence of a saline, oxidized and possibly acid fluid, suggest an intrusion-related model. The presence of the hydrothermally altered dioritic intrusion(s) and the contactmetamorphic aureole support this hypothesis.

The timing of mineralization is also unknown. The presence of shear zones within the diorite intrusion(s), together with the venulation and brecciation transgressive with respect to regional foliation indicate that magmatism and hydrothermal activity took place in the latest stages of evolution of the Cinzento strike-slip system.

Acknowledgments The authors wish to thank the Companhia Vale do Rio Doce for authorizing the publication of their private data. We are also indebted to all the geologists of Rio Doce Geologia e Mineração S.A. (DOCEGEO) that took part in the Serra Pelada and Serra Leste Projects. Richard Sillitoe deserves a special vote of thanks for his comments that greatly improved our original ideas. We acknowledge the referees of RBG and also all the anonymous reviewers that enhanced our original manuscript. The first author is indebted to FAPESP (Fundação de Amparo a Pesquisa do Estado de São Paulo) for the grants \#98/14401-5 and \#99/03058-0.

\section{References}

Barton P.B. 1993. Problems and opportunities for mineral deposit models. In: R.V. Kirkham W.D. Sinclair; R.I. Thrope; J.M. Duke (eds) Mineral Deposit Modeling. Geologica Association of Canada, Special Paper 40, 7-13

Berger B.R. \& Bagby W.C. 1993. The geology and origin of Carlin-type gold deposits. In R.P. Foster (ed) Gold Metallogeny and Exploration. London, Chapman \& Hall, 210248

Cathelineau M. 1988. Cation site occupancy in chlorites and illites as a function of temperature. Clay Minerals, 23:471-485

CVRD (Cia Vale do Rio Doce). 1998. I Workshop Sobre a Geologia de Serra Leste - Relatório. CVRD (internal report), $5 \mathrm{p}$.

Davidson G.J \& Large R.R. 1994. Gold metallogeny and the copper-gold association of Australian Proterozoic. Mineralium Deposita, 29:208-223

Diella V., Ferrario A., Girardi V.A.V. 1995. PGE and PGM in the Luanga mafic-ultramafic intrusion in Serra dos Carajás (Pará State, Brazil). Ore Geology Reviews, 9:445-453

DOCEGEO (Rio Doce Geologia e Mineração S.A.). 1988. Província Mineral de Carajás. Litoestratigrafia e principais depósitos minerais. In: SBG, Congresso Brasileiro de Geologia, 35, Belém, Anexo aos Anais, 165p.

DOCEGEO (Rio Doce Geologia e Mineração S.A.). 1995. Relatório de Etapa. Alvo Serra Leste. Belém, DOCEGEO (internal report), 150p.

Einaudi M.T., Meinert L.D., Newberry, R.J. 1981. Skarn deposits. Economic Geology, $75^{\text {th }}$ Anniversary Volume: 317-391

Hirata W.K. 1982. Geologia Regional. In: SBG, Simpósio de Geologia da Amazônia, 1, Belém, Anexo aos Anais, 9-20

Machado N., Lindenmayer Z, Krogh T.E., Lindenmayer D. 1991. U-Pb geochronology of Archean magmatism and basement reactivation in the Carajás area, Amazon Shield, Archean magmatism and basement reactivation
Brazil. Precambrian Research, 49:329-354

Meireles E.M. \& Silva A.R.B. 1988. Depósito de ouro de Serra Pelada, Marabá, Pará. In: C. Schobbenhaus; C.E.S. Coelho (eds) Principais Depósitos Minerais do Brasil, volume 3. Brasília, DNPM/CVRD, 547-557

Mikucki E.J. \& Ridley J.R. 1993. The hydrothermal fluids of Archean lode-gold deposits at different metamorphic grades: compositional contraints from ore and wallrock alteration assemblages. Mineralium Deposita, 28:469-481
Mountain B.W. \& Wood S.A. 1988. Solubility and transport of platinum-group elements in hydrothermal solutions: thermodynamic and physical chemical constraints. In: H.M. Prichard; P.J. Potts; J.F.W. Bowles; S.J. Cribb (eds) Geo-platinum 87. London, Elsevier, 57-82

Pinheiro R.V.L. \& Holdsworth R.E. 1995. Significado tectônico da clivagem transversa (transecting cleavage) em dobras na mina de Serra Pelada, Pará. Boletim do Museu Paraense Emílio Goeldi, Série Ciências da Terra, 7:289-308

Pinheiro R.V.L. \& Holdsworth R.E. 1997. Reactivation of Archean strike-slip fault systems, Amazon region, Brazil. Journal of the Geological Society, 154:99-103

Sillitoe R.H. 1998. Geological model and exploration potential, Serra Leste Gold Deposit, Carajás Region, Brazil. CVRD (internal report), $15 \mathrm{p}$.

Suita M.T.F. \& Nilson, A.A. 1988. Geologia do Complexo Máfico-Ultramáfico Luanga (Província de Carajás, Pará) e das unidades encaixantes. In: SBG, Congresso Brasileiro de Geologia, 35, Belém, Anais, 6:2813-2823

Tassinari C.C.G. \& Macambira, M.J.B. 1999. Geochronological provinces of the Amazon Craton. Episodes, 22:174-182

Tracy R.J. \& Frost B.R, 1991. Phase equilibria and thermobarometry of calcareous, ultramafic and mafic rocks, and iron formations. In: D.M. Kerrick (ed) Contact Metamorphism. Min. Soc. America, Reviews in Mineralogy, Volume 26, 207-290

Vidal C.E., Espinoza J.I., Sidder G.B., Mukasa S.B. 1990. Amphibolitic Cu-Fe skarn deposits in the Central Coast of Peru. Economic Geology, 85:1447-1461

Watkinson D.H. \& Melling D.R. 1992. Hydrothermal origin of platinum-group mineralization in low-temperature copper sulfide-rich assemblages, Salt Chuck Intrusion, Alaska. Economic Geology, 87: 175-184
Contribution IGC-075 Received February 2, 2000 Accepted for publication April 30, 2000 